\title{
Entrevista com Leandro Vieira
}

com a participação de Alexandre Sá, Cláudia Saldanha, Inês de Araujo, Felipe Ferreira e Luiz Guilherme Vergara.

Fotografia e filmagem João Paulo Racy. 
Felipe Ferreira Hoje é dia 16 de outubro. Estamos aqui para bater um papo com o Leandro Vieira, carnavalesco da Mangueira e da Imperatriz Leopoldinense. Esta entrevista para a revista Concinnitas, será publicada em seu próximo número acompanhada por um dossiê sobre a Mangueira. A ideia é conversar um pouco sobre você, sobre seu trabalho e sua relação com o mundo da arte. A Concinnitas é uma revista do Instituto de Artes da Uerj, portanto ela aborda sempre a questão da arte, das suas relações com a contemporaneidade, com a arte contemporânea e com a universidade.

Então Leandro, só para fazer uma pequena apresentação sua já te faço uma primeira pergunta. A gente sabe que você tem toda uma relação, um interesse por esse diálogo com a arte, com o mundo da arte. Essa é uma das suas características na verdade como carnavalesco. Mas a tua trajetória foi muito rápida. Como é que era isso antes de você se tornar um carnavalesco, quando você era figurinista, quando você estava na Escola de Belas Artes? Ou seja, como é que era essa tua relação, a tua perspectiva de pensar a relação com o mundo da arte?

Leandro Vieira Com relação a essa questão da minha relação com a arte e o carnaval acho que a coisa mais importante que deve ser dita é que, nunca, em momento nenhum, eu pensei em ser carnavalesco. Eu sempre quis produzir arte. Essa arte, vamos dizer assim, mais institucional. A arte das galerias, a questão da instalação, da arte contemporânea, da pintura. Então eu entrei para a Escola de Belas Artes, uma formação diferente até de muitos carnavalescos. As pessoas têm essa ideia do carnavalesco que vem da Escolas de Belas Artes. Mas o carnavalesco que vem da Escola de Belas Artes, historicamente, no mundo do carnaval, é o cenógrafo e o figurinista. Eu sou pintor por formação. Eu entrei para a Escola de Belas Artes para fazer pintura. E dentro da Escola de Belas Artes, a partir do meu contato com a pintura, resolvi que meu caminho era a questão da pintura contemporânea, da instalação, outro universo de arte. Até então, o desfile das Escolas de Samba, para mim, era algo que acontecia no carnaval, e que eu tomava conhecimento pela televisão. Nunca olhei um desfile de Escolas de Samba com a intenção de ser carnavalesco. Tem um outro dado importante nisso. Eu olhava o desfile de escola de samba com o interesse de ser um folião de escola de samba, porque eu sempre gostei do carnaval, mas do carnaval enquanto atividade cultural, uma manifestação que ganha a rua, um espaço político de ocupação. Esse carnaval sempre me interessou. Então a minha ligação com o carnaval ela é inicialmente em função dos blocos de 
rua, em função desse carnaval mais de gueto e não do carnaval institucional que é propagandista da escola de samba. Eu vivi o momento da retomada do carnaval de rua da cidade, do crescimento dos grandes blocos. E eu participei disso de uma outra forma. Então a primeira coisa da minha relação com a arte e o carnaval é essa. Quando eu comecei a ter contato com o universo das Escolas de Samba, antes de ser o figurinista, antes de ser o desenhista de carnaval, meu primeiro contato com esse universo foi muito mais ligado à pesquisa, porque eu gostava da questão teórica da arte. E o carnaval das escolas de samba tem todo um embasamento, pouca gente sabe disso, mas ele é feito a partir de um embasamento inicialmente teórico. Claro que o visual, a questão da festa, a maneira como a festa é transmitida, faz isso ficar menor, porque de alguma forma o canto, a dança e a plasticidade se sobrepõem a essa parte do conteúdo teórico do carnaval. Mas quando eu comecei a fazer parte de equipes de criação de desfiles de escolas de samba, eu fui trabalhar para embasar teoricamente os projetos. E aí, já dentro de uma sala de um barracão, comecei a colorir figurinos, já que eu dominava técnicas de pintura, aquarela, nanquim, essa coisa toda. Num determinado momento, depois que passei a colorir figurinos, comecei a entender que eu podia olhar o desenho de alguém e fazer igual. E comecei a desenhar, a colorir e a pesquisar. E assim eu fiquei durante dez anos nos bastidores das escolas de samba. Eu tinha inclusive o pensamento preconceituoso desse carnaval enquanto uma atividade artisticamente menor. E eu estava muito satisfeito com essa questão de desenhar e ser figurinista. Entretanto, por minha natureza de mergulhar no que eu faço, comecei a pesquisar figurino de carnaval. Na verdade, eu nem me acho um figurinista de carnaval, nem um cenógrafo, mas um pintor que faz carnaval. Um pintor que brincou na rua, que faz carnaval e tem uma visão de arte. É então que um tropeço me levou a ser carnavalesco. Eu era figurinista da Imperatriz Leopoldinense e fui demitido. A partir dessa demissão eu recebi um convite de uma escola de samba, a Caprichosos de Pilares, carnavalesco nenhum queria ser carnavalesco da Caprichosos de Pilares. Eu recebi o convite e aceitei porque estava desempregado. Porque se eu não estivesse desempregado eu não aceitaria. E assumi o carnaval da escola. Inclusive, no começo, eu tinha muita dificuldade com o nome "carnavalesco", de me dizer que eu era um carnavalesco, de me intitular carnavalesco, eu me dizia que eu era um artista que fazia carnaval

Inês de Araujo Você trabalhou com uma equipe para a Caprichosos de Pilares? 
LV Existe a equipe que executa e a equipe que cria. Desde que eu me tornei carnavalesco, há 5 carnavais, eu nunca tive uma equipe de criação, a equipe sempre fui eu. Eu nunca tive um assistente. Quando eu cheguei à condição de dito carnavalesco, assumi esse papel, e quis fazer as coisas que eu acreditava que eram importantes fazer. Se eu tivesse que fazer alguma atividade artística para o carnaval eu queria fazer embasado teoricamente, eu queria que os materiais se falassem. Eu queria que não fosse uma coisa meramente estética, vazia. Eu quis colocar o conceito que eu carrego a respeito do carnaval. E busquei transformar minhas propostas em propostas artisticamente mais densas e mergulhadas no universo de arte contemporânea, da relação com diferentes correntes artísticas e com artistas que eu admirava. Sempre que eu posso, uso referências do grafite, da Street Art, monumentos...

IA Tem uma coisa muito forte dos materiais no seu trabalho, que você usa propositalmente, quase contra essa espetacularidade do carnaval. É uma visão muito fora da curva.

LV Eu tento combater esse carnaval da estética, da opulência. Mas isso é uma viagem muito louca, porque é uma bacia com muita coisa dentro. Então as vezes eu vou para o lado da opulência, mas misturada com outras coisas. Mas eu tenho uma tendência à desconstrução, eu acho que eu tenho uma tendência a fazer meu carnaval desconstruindo coisas.

IA Mas isso acontece conversando com outros carnavalescos, quando você faz manobras de modificar essa estética? Isso dialoga com muitas referências, você falou em muitos artistas.

LV Sim, tem muita. Eu tenho muitas referências. Depois que eu comecei a fazer carnaval, aí você começa a olhar os artistas das escolas de samba, suas maneiras de criar e você vai encontrando seus pares, suas referências estéticas, pessoas que talvez mergulhem num universo que te acrescenta esteticamente, ou te acrescenta conceitualmente. Aí você começa a ter esse diálogo. Eu acho que de alguma forma eu sou um carnavalesco tradicional. Minha criação carnavalesca talvez tenha uma vocação a ser tradicional, no sentido do fazer. Mas quando eu me refiro ao carnaval tradicional, talvez não seja aquele que é feito hoje, mas o que já foi feito. Eu tenho uma visão da atividade artística do carnaval de 
escola de samba, como algo um pouco mambembe. Eu vejo um desfile dos anos 70 e acho que aquela coisa mal-ajambrada é muito carnavalesca. Então eu busco não perder esse contorno imperfeito. Eu gosto do torto, eu gosto do que não se combina, do que está propositalmente torto, do que se coloca à mostra. Eu gosto de produzir as coisas assim. O feio sempre foi um dado importante para mim. Me preocupar com o feio. Eu nunca quis ser muito bonito. Claro que tem uma preocupação estética, mas o feio é um dado do meu trabalho, dessa coisa mal construída, construída para parecer esquisita.

IA Nisso tem muito de uma estética popular, de coisas que você encontra em todos os lugares. Fico me perguntando se o que você está falando desse feio não tem esse olhar.

LV Tem. Eu vou te dar exemplos práticos. Vou falar por exemplo do carnaval que eu fiz na Mangueira sobre a religiosidade popular. Ao mesmo tempo que eu tinha um abre-alas em que a estética do barroco opulento dominava tudo, os santos desse carro, eram propositalmente arranhados, desgastados pelo tempo. Os oratórios eram todos envelhecidos, com uma pintura mal feita. Algo que já foi bonito e ficou feio com a ação do tempo. Ao mesmo tempo que tinham figuras com São Benedito, super clássico, com a referência da escultura em madeira portuguesa, e uma Nossa Senhora da Conceição, do barroco baiano, tinha também, na traseira, ex votos mal feitos. Essa coisa tosca. Esteticamente me agrada trabalhar com o contorno tosco que as coisas podem ter. Nesse mesmo desfile, no carro da festa de lemanjá eu queria fazer uma coisa naif. Eu ainda estava impregnado da minha memória da festa de lemanjá em Rio Vermelho aonde fui um ano antes, daqueles barquinhos mal feitos, mal pintados, aquela coisa quase ingênua. E aquilo era um dado que eu queria que estivesse no desfile, tratando da questão da religiosidade popular, para celebrar, numa alegoria, uma santa celebrada pelas pessoas mais humildes. Então tudo isso é um dado do trabalho.

IA Mas deve ser complicado de fazer.

LV É complicado de fazer, primeiro porque os próprios profissionais do carnaval têm uma tendência ao belo. Então muita coisa eu tenho que deixar fazer bonito e, depois, pegar uma faca e quebrar. Quebra aqui, 
corta aqui, racha. Por exemplo, no mesmo carnaval sobre religiosidade, a última alegoria tinha uma escultura que era uma face de machado de Xangô, feita de madeira. Eu queria fazer um traço bem de madeira com a influência da mão africana e pedi que rachassem a máscara do começo ao fim, tudo evidenciado pela pintura de arte para destacar que era rachado. E várias pessoas me perguntavam se aquela peça tinha rachado de verdade, se aquilo era um defeito.

Alexandre Sá Leandro, voltando um pouco à ideia de ingenuidade, eu te pediria para falar um pouco mais dessa ideia de espetáculo e "nãoespetáculo". Algumas vezes você falou assim, "eu não aceito que seja só espetáculo". E fiquei me perguntando se ainda é possivel hoje essa mediação. Por exemplo: Parintins, a Festa de lemanjá. Quem consegue escapar dessa lógica do espetáculo? Mesmo a própria Apoteose, aquelas luzes, todo o universo midiático, enfim... Como você pensa essa relação tão fina, tão particular? Esse desejo de não ser espetáculo numa estrutura que já se coloca como espetacular...

LV Na minha cabeça eu faço um negócio que depois levam para Avenida. Então quando pegam tudo que eu faço e jogam na Avenida, vira espetáculo. Mas na minha construção aqui, na maneira como eu faço a construção, desenvolvo conceitualmente o desfile, nada é feito para o espetáculo. É como se eu pegasse as coisas que eu faço aqui e alguém colocasse num lugar onde se realiza o espetáculo. E aí ele ganha o contorno que tem lá, ele ganha aquela luz que já tem lá. Mas não é construído aqui para isso. As vezes é construído para ser feio, mas talvez quando chegue lá achem bonito. Eu tenho essa preocupação e nego determinadas coisas. Por exemplo, o dito efeito especial do carnaval. O efeito especial do carnaval de hoje em dia é LED, iluminação, fumaça. Eu nego tudo isso. As pessoas acham que eu uso lâmpada "bolinha" na Mangueira porque a escola não tem dinheiro. Não, eu uso porque eu quero usar lâmpada bolinha. Porque lâmpada bolinha é a gambiarra. Por exemplo, o vime, uma estrutura muito utilizada no carnaval, eu quase sempre uso de forma aparente. Tradicionalmente ele serve de estrutura para jogar pano em cima. Vime é uma espécie de madeira que eu uso envernizado. Eu não mando pintar e, quase sempre, eu ainda mando envelhecer o vime, para ele parecer madeira velha. Eu nego a questão do espetáculo negando o LED, negando alguns recursos artísticos comuns que são usados na construção estética do carnaval contemporâneo. 
FF Pensando em termos de arte e de produção de arte, você seria, digamos assim, um artista que trabalha para o ateliê e não para uma galeria. Você não cria na expectativa da exposição, mas para o barracão, é isso?

LV Sim, é pior ainda, eu trabalho pra mim. Mas eu sei que meu trabalho vai desfilar, eu sei que ele se comporta em conjunto. Isso é um dado importante do carnaval, como as coisas se comportam em conjunto. Aí nessa hora eu sou mais o pintor, o pintor que vê, que tem o olhar da pintura, do conjunto. Se ele quer deixar uma coisa para o fundo ele vai azulando, se ele quer botar uma coisa para frente ele vai esquentando. Eu tenho essa noção. Quando eu construo o meu carnaval e vejo a tela, eu busco construir com essa lógica. Eu acho que enquanto figurinista eu sou muito mais pintor.

FF Você trabalha muito com essa noção de conjunto então, com essa ideia de conjunto da ala, né?

LV É, do diálogo da ala com o carro, da sensação que a cor da ala provoca no olhar de quem tem um determinado conjunto visual. Isso eu tenho muito mesmo.

Claudia Saldanha É assim que você constrói o enredo, não é? Você vai contando uma história ao longo da avenida, qual ala vem primeiro, qual ala vem depois, e isso faz parte desse processo de criação. Você prefere ser chamado de carnavalesco ou de artista?

LV Eu ainda não consegui decidir, ainda não consegui saber. Eu acho que cada vez mais eu tenho entendido que o carnavalesco é o artista, mas eu ainda estou encontrando um meio termo disso. Eu acho que a figura do carnavalesco artista, por uma série de motivos, foi se esvaziando. Talvez porque o carnaval tenha passado por um momento em que ele também começou a esvaziar o conteúdo das coisas. E aí a questão da arte pela arte ela acabou também se esvaziando e os carnavalescos ficaram numa entressafra e virou tudo muito decoração. Virou quadro para enfeitar parede. E isso bagunça um pouco minha cabeça. 
AS Eu queria voltar um pouco. Você estava falando da Caprichosos. Depois você vai para a Mangueira e faz um carnaval vitorioso. Como é que isso se dá? Como você recebe isso? E uma última pergunta... Você está comentando esse tipo de carnaval que tenho a impressão de só se realizar pela generosidade que comunidade representa. Você sente isso? A Mangueira... Como ela abraça isso?

LV Então, vamos por partes. Eu comecei na Caprichosos de Pilares, com essa experiência de fazer o meu primeiro carnaval. Aí eu recebi o convite da Mangueira. E isso é uma situação do meu trabalho que é muito louca. Uma pessoa que não imaginava nem ser carnavalesco, no ano seguinte se torna carnavalesco da Mangueira. É muita loucura para uma pessoa. É uma surpresa você chegar e receber o convite para ser o carnavalesco da Mangueira. E a verdade é que eu não sabia nem se eu sabia fazer carnaval. Será que eu sei fazer carnaval? Será que eu sei fazer isso? Pegar uma escola do tamanho da Mangueira e fazer? Eu não sei se eu fui corajoso. Eu acho que eu não parei para dimensionar o que podia ocorrer. E aceitei. E tem um dado curioso nisso, a Mangueira ficou em décimo lugar no ano anterior. Então eu pensei assim, "Mangueira, um escolão do tamanho desses, pior que o décimo não fica até se eu fizer merda, por que, pô, vão derrubar a Mangueira? A Mangueira vai cair? Não vai". Então eu fui muito nessa ideia, tipo, pior do que o décimo eu acho que eu não fico. E eu aceitei fazer. E acho que muito do campeonato tem a ver com meu descompromisso com o acerto. Porque eu não vim para ganhar, eu vim para ficar em décimo lugar. E fiquei em primeiro. Acho que é isso, o meu descompromisso com a vontade de acertar. Escola de samba tem suas questões políticas, suas gestões e tal, e o panorama que me antecedia, o panorama de contratações que me antecedia era o seguinte: a escola passou por eleições, um novo presidente assumiu a escola, o Chiquinho da Mangueira. Ele contratou aquela que eu considero a maior carnavalesca da história dos desfiles de Escolas de Samba, Rosa Magalhães, campeã com a Vila Isabel. Eu não sei direito, mas acho que ficou em nono lugar. A partir dessa colocação, carnaval tem muito isso. Não deu certo? Dispensa. Aí dispensaram a Rosa e contrataram um segundo profissional que já tinha uma experiência com a Mangueira, que é o Cid Carvalho, um carnavalesco campeão, com experiência no carnaval, foi campeão diversas vezes com a Beija-Flor, já havia feito Mangueira numa condição financeira muito ruim em gestões anteriores. Foi contratado e ficou em décimo lugar. Então foi dispensado. Eu fui contratado no último ano do mandato desse presidente que, em 2014, dispensou a Rosa Magalhães, em 2015 dispensou o Cid Carvalho e que, na minha cabeça, em 2016, dispensaria 
o Leandro Vieira. E eu sei que eu fui contratado porque a escola passava por uma situação financeira ruim, tinha contratado dois anos antes, a bambambam do carnaval por um valor com certeza considerável, havia contratado um outro carnavalesco campeão, com certeza por um valor considerável, e o presidente estava contratando para jogar a toalha no último ano, "se eu não ganhei com a Rosa, se eu não ganhei com o Cid, é melhor eu perder gastando menos, vai o Leandro mesmo que, se eu perder, perdi gastando menos". Aí eu fui contratado e aceitei fazer. A escola ficou procurando enredo e perguntaram se eu tinha algum. Eu propus o enredo da Bethânia e as coisas foram acontecendo. Mas eu não tinha o compromisso de ganhar. E isso de não ter o compromisso de ganhar ajuda muito, porque eu acho que quem faz o carnaval querendo ganhar começa perdendo. Porque aí ele recorre a vícios que possam levar ao campeonato. Eu poderia ter embarcado na ideia de que a melhor Mangueira é a Mangueira verde e rosa, achando que o campeonato estava em cima disso. E eu não fiz isso. Talvez esse ano tenha sido a ruptura da Escola com o Verde e Rosa. Eu desenhei o carnaval de 2016 todo a nanquim, comecei a fazer verde e rosa, mas eu não gostava de absolutamente nada, para mim tudo que eu fazia era feio. Eu não conseguia combinar, eu não conseguia me satisfazer enquanto pintor. Aí eu falei assim, vou fazer outra coisa, vou refazer os nanquins, a criação. Xeroquei todos os figurinos riscados a nanquim e comecei a variar em cima deles: "verde e rosa, não gostei, verde, rosa e azul, não, tira o verde e deixa o azul com o rosa, não, bota o vermelho com o rosa, tira o verde, não, bota o verde água,". Então o mesmo figurino foi pintado cinco vezes em propostas diferentes, até eu encontrar caminhos, ou até eu encontrar impossibilidades de fazer. $\mathrm{E}$ diante de reconhecer que eu não sabia fazer verde e rosa, eu preferi fazer o que eu achava que eu faria melhor, que foi tirar o verde e rosa e combinar em momentos...

\section{CS $E$ houve muita resistência na Escola?}

LV Todas. Tem uma história clássica a respeito disso com o abre-alas da Mangueira. Ele era dourado e palha e a Escola, tradicionalmente, se reconhece no verde e rosa. E o meu último carro, onde vinha a Bethânia, era um que tinha verde e rosa. Eu acho o abre-alas de 2016 uma das construções artísticas mais bonitas que eu fiz para o carnaval. Ele foi construído aqui dentro, as pessoas o achavam bonito. $\mathrm{E}$ o último carro que encerrava o desfile, era um circo. E já era um circo mais dessa estética que eu gosto, do circo do interior, do circo mambembe e tal. E 
ele era verde e rosa. Então os Mangueirenses que chegavam no barracão, quando viam o último carro, já diziam, o abre-alas tá lindo (risos). E eu, percebendo que eles reconheciam aquilo como o abre-alas, dizia que era o abre-alas. O outro era bonito, mas o lindo era o verde e rosa.

IA Mas até quando dura essa negociação? Uma hora o pessoal tem que saber a verdade.

LV No dia, na hora do desfile, na concentração. Primeiro, que eu não era conhecido como carnavalesco, então as pessoas me viam lá - eu era um cara de trinta anos de camiseta, short e chinelo - elas chegavam e não me reconheciam como carnavalesco da Mangueira. E o que elas mais me perguntavam era, "Que escola é essa?". Aí eu falava "é a Mangueira". Teve um senhor até que se revoltou, que a Mangueira não era aquilo, que a Mangueira era verde e rosa, se revoltou comigo, mas sem saber que eu era o carnavalesco. Eu não falei nada.

FF Tem duas coisas que eu acho interessante. Primeiro, não era só o abrealas que era dourado e palha. Era toda a escola. Era realmente preocupante imaginar o que podia acontecer. Eu vi e fiquei imaginando como é que seria a reação. Mas por outro lado a escola tinha as cores verde e rosa. Era um verdinho aqui, um rosinha ali, e aquilo, no final das contas, era percebido, no conjunto como verde e rosa.

LV Eu trabalho muito isso. Ultimamente as pessoas têm tido a sensação que a Mangueira está verde e rosa, sem estar.

FF Tinha essa coisa, mas não chocou. Porque a Mangueira já tinha vindo sem suas cores e foi um choque na época. Foi um problema, um impacto, todo mundo reclamando depois do desfile. E nesse ano não. A Mangueira acabou ganhando, então acho interessante pensar sobre isso. Outra coisa interessante é que antigamente os carnavalescos, meio que montavam a escola na hora. Há relatos do Arlindo Rodrigues, que juntava a escola na concentração e dizia: não, pera aí, "pega aquela ala e bota lá na frente, ou tira aquele carro, é esse carro aqui que vai ser o abre-alas". Tinha essa questão, hoje em dia isso não existe mais, mas ao mesmo tempo, de uma certa forma o que você fez é uma referência a isso né. 
LV Eu faço muito isso aqui dentro do barracão. Isso é uma coisa que tem a ver com meu trabalho, da maneira como eu organizo as minhas ideias. Vou dar um exemplo. Vou fazer um tripé, o tripé é um elemento cenográfico menor do que uma alegoria. Inicialmente eu faço ele para estar entre o segundo e o terceiro carro. Mas ao fazer aqui dentro eu o jogo para o final. Eu tenho essa coisa de contornar. Eu não gosto de fechar o meu projeto, eu não gosto de fechar o que eu vou fazer antecipadamente. Hoje cada vez mais eu gosto de trabalhar menos com o projeto. Para o carnaval do ano que vem eu já mudei várias coisas a partir desse olhar estético.

Voltando para o que você perguntou, eu jogo o tempo todo com a força da comunidade que eu represento e que eu visto. Algumas pessoas dizem que eu sou a cara da Mangueira, que eu faço um carnaval que é a cara da Mangueira, que eu faço um carnaval para a Mangueira. E na verdade eu não tenho essa preocupação. Eu não faço nada achando que eu estou fazendo algo a cara da Mangueira. Eu sempre estou interessado em me agradar primeiro. Isso parece um pensamento egoísta, uma coisa vaidosa, mas não é. Porque na verdade eu e a Mangueira temos uma afinidade que não é estética. Se você for pegar historicamente a estética da Mangueira, ela sempre foi uma escola com pouco compromisso estético. A Mangueira nunca foi a escola que se preocupou com estética. A escola sempre foi aquela mais pobre. Não julgando questão de carnavalescos melhores ou piores, mas a Mangueira, com exceção talvez dos carnavais do Max, nunca foi, por exemplo, como a Imperatriz. A Imperatriz era uma escola de estética, ela foi esteticamente forjada por carnavalescos da linguagem plástica: Arlindo Rodrigues, Viriato. Max Lopes e Rosa Magalhães. O Salgueiro dos últimos 15 anos ganhou o contorno do Renato Lage, um esteta absoluto. A Mocidade boa é a mocidade do Renato Lage. A Beija-Flor boa é a Beija-Flor do João, da escola do João. A escola se reconhece quando ela está vestida a maneira João Trinta. O Salgueiro bom é o Salgueiro afro, tem essa mítica, porque tem a ligação disso com o Fernando Pamplona. Então tem toda essa questão. E a Mangueira não, a Mangueira não tem essa questão. Eu acho que ainda não tem.

IA Mas você diria que tem uma questão, pelos carnavais que você faz, com a narrativa do presente, "na luta nós nos encontramos", enfim, com essa dimensão política, que foi muito forte nesses últimos carnavais. 
LV Eu acho que eu tenho sugerido coisas. Aí que eu digo, eu e a Mangueira nós temos muita coisa em comum. Eu acho que eu dou certo aqui, não porque faço algo com a cara da Mangueira. Eu faço algo que tem a minha cara e que de alguma forma tem ligação com a Mangueira. Então acho que a escola se reconhece no que eu proponho. E até porque o que eu proponho sempre tem a questão popular, tem essa relação.

IA Mas um popular nada mistificado, né? O que é muito diferente de uma ideia folclórica que se tem do que que seria arte popular. Um popular ligado à vida dessa comunidade, à sua energia e quase ação. Você vê isso como uma marca nessa história que você está traçando?

LV Eu tenho dificuldade de olhar para o meu trabalho em cinco carnavais como algo que tenha essa personalidade, porque eu tenho ainda muita dificuldade de fazer carnaval. As pessoas vêem meu trabalho pronto, elas não sabem o que eu passo para chegar até ali, e não sabem da minha insatisfação com certas dificuldades do fazer. Então eu ainda tenho muita dificuldade de olhar a coisa com essa personalidade.

IA Mas essas experiências desses cinco últimos carnavais, elas deixam um lastro.

LV Sim, os acertos e os erros também. E eu contabilizo muito meus erros, então eu tenho dificuldade de botar agora um rótulo no que eu estou fazendo. Muita dificuldade.

FF Você acha que essa experiência de você aceitar fazer duas escolas ao mesmo tempo tem a ver com essa questão?

LV Tem a ver com o desafio. Tem a ver com a questão de uma provocação minha comigo mesmo. De eu me provocar, de eu me questionar. Vamos supor assim, de alguma forma, em quatro carnavais, quatro carnavais e dois campeonato, eu tenho a sensação de que pintei até aqui uma tela bonita. E eu queria fazer mais. Eu estou fazendo um carnaval para um bicampeonato. Isso é muito confortável. É muito confortável você ficar nesse lugar. E aí eu queria me desafiar de alguma 
forma, fazer o grupo de acesso, fazer a Imperatriz que é uma super escola.

CS A iniciativa foi sua ou você foi convidado?

LV Eles me convidaram, mas eu podia dizer que não. E eu achei que era bom. O desafio, a crítica. Essa coisa de dizer que eu sou mercenário, que eu estou fazendo para ganhar dinheiro, que não precisava. $E$ de experimentar uma outra possibilidade artística, mais leve, um outro cenário de produção. Eu estou fazendo Jesus e o Lamartine Babo. São lugares muito distintos. $\mathrm{E}$ a seriedade do sagrado com o libertino da rua, com o Maracanã das torcidas, é diferente.

FF Você acha que o pensamento de um reflete para um lado e para o outro?

LV Tenho certeza absoluta que um conversa com o outro, mas eu tenho mais certeza que os dois conversam com o Leandro. Eu podia ter escolhido outra coisa para fazer a Imperatriz, mas escolhi o Lamartine, por causa da rua, porque o Lamartine é o futebol, é a festa junina, Lamartine são as marchinhas do carnaval de rua, Lamartine é o pirata, a Colombina, o Pierrot. É um universo do carnaval que eu gosto.

AS Na Mangueira você vai falar um pouco dos discursos minoritários... Em certo sentido tem essa relação que a Inês está pontuando, não?

LV A Mangueira tem muito da rua também. Aliás, a minha produção artística conversa muito com a rua, com as coisas da rua. Tem uma unidade entre todos os enredos. Todos olham muito para rua.

Guilherme Vergara Vou pegar talvez uma contramão aqui. Eu gostaria de recuperar um pouco do início da conversa. Me chamou a atenção que você falou da sua relação com a pintura. Isso me surpreendeu porque eu não esperava isso. Quando você fez essa relação, você falou muito de embasamentos teóricos, você fez a Belas Artes. E aí tem toda uma dobradura que você está exercendo. $E$ essa dobradura tem história no 
Brasil, principalmente na Mangueira. Você deve ter tido contato, e sempre ouviu falar da relação do Hélio Oiticica com a Mangueira, mas também não sei se você já ouviu falar de todo o estudo do Israel Pedrosa, que começa a estudar as massas de cores para as filmagens da televisão nos desfiles, e passa a pensar massas de cores. E ele é um pintor, que tem a teoria da cor inexistente. $E$ a todo momento o que me chama a atenção é que você tem consciência de conceitos de friç̧ões muito boas, porque quando a gente pensa cor, a gente pensa luz e tudo. Mas ao mesmo tempo você fala dessa gambiarra, desse precário e aí é matéria.

LV Mas na pintura para mim isso é a textura. Tem a cor e acho que tem a textura.

GV Quando eu penso do não acabamento eu não pensaria só da textura, mas também uma rachadura...

LV Sabe o pintor quando usa a espátula? Quando pega a ponta da bisnaga de tinta, tem isso. Porque até quando eu pintava eu não gostava de pintar bonito.

GV É, você está usando essas palavras, do feio, do tosco, da gambiarra. Estou imaginando essas maneiras que você coloca quando você vai para o desenhar.

LV Eu gosto da pintura do Vik Muniz.

GV Principalmente o efeito que ela faz em um galpão imenso, depois você vê aquilo ali e você não identifica que aquilo ali é feito de lixo.

LV Exatamente, lixo, macarrão...

GV Mas, ao mesmo tempo, ele pensa um resultado plástico em grande escala. E isso me chama muita atenção, por esses seus sentidos de ir para o campo da arte. Quando o Felipe me convidou pensei, essa inflexão tem história, seja um Hélio Oiticica querendo ir para a Mangueira porque ele estava descontente com esse mundo. Você conquistou o que talvez seja o 
mais importante do contemporâneo, é pensar uma arte cuja vivência é coletiva. Eu acho que aí você dá uma potência daquilo que seja uma fricção do século vinte, mas já é uma antecipação de um pensar de transporte e dobradura do contemporâneo. Porque tudo que você fala eu fico pensando "ah, eu fiz o trabalho com nanquim aí fui testando". E aí você está pensando em uma escala, mas depois tem a outra escala que é um sistema de massas pulsantes.

LV É arte para vestir. Quando eu faço escola de samba, quando eu desenvolvo um figurino que vai se comportar dentro de um conjunto eu penso em Arte para vestir. Você falou no Helio Oiticica. Então, muito do que eu faço, o comportamento daquilo é Parangolé. É bandeira para vestir, é o movimento que sacode a bandeira, é a pluma que balança, é o pompom na ponta de uma vareta que fica assim. Então fantasia de escola de samba é bandeira para vestir.

GV É algo que para mim é muito forte, que a escola de samba se torna um corpo de múltiplos corpos, então você veste um e veste o corpo inteiro de múltiplos corpos. Essa visão que é uma visão que nenhum pintor tem. Então como é que foi essa apreensão dessa experimentação.

LV Tem, por que eu sou pintor. Eu olho para aquilo como pintura. É muito difícil eu ficar falando a respeito disso porque eu falo com esse olhar do pintor. As pessoas falam assim "ah, seu trabalho é diferente do trabalho de fulano no carnaval". É porque eu acho que o olhar é de fato diferente pela minha formação. Historicamente, a Escola de Belas Artes forneceu para o carnaval carioca figurinistas e cenógrafos. E eu sou pintor. E aí eu vou mencionar algumas fantasias. Eu tinha um setor ano passado de fantasias indígenas e aí eu fiz algumas coisas com pena de arara. Mas o que fascina o pintor em uma arara, em uma arara azul, são as nuances de arara azul que tem numa única pena de arara. É a pena azul que num determinado momento recebe um vermelhão, ali por dentro ela fica azul e vermelha. Um papagaio, que é verde, aquele verde que é quase um verde limão, mas entra por ali um pouco de azul turquesa. E aí eu ficava pensando assim, quero fazer uma coisa indígena, cocares. Aí vou trabalhar com essa ideia dos cocares. Mas qual é a cor do cocar? Quero fazer um cocar verde, quero fazer uma ala do cocar verde, uma ala do cocar amarelo, uma ala do cocar vermelho, uma ala do cocar azul. Aí eu mandei fazer as penas, e o cara produziu para mim uma pena de arara azul, uma pena de papagaio verde, uma pena de arara vermelha 
e tal. Eu comecei a montar os resplendores e quando eu montei aquelas penas, ficou tudo vermelho. E eu sabia que aquilo, quando se comportasse no conjunto, ia ficar tudo vermelho. Eu queria era ver o vermelho, mas eu queria que entrasse um azul turquesa dentro do vermelho em alguns momentos, como quando - e aí eu vou usar pintura - você está ali com as tintas na paleta e com o lado direito do pincel esbarra no azul e com o lado esquerdo você esbarra no vermelho, e você dá aquela pincelada solta e o azul ganha um contorno vermelho. Eu queria que o meu vermelho num determinado momento, ganhasse uma pincelada de azul. E cheguei à conclusão que para eu conseguir isso no todo, não adiantava eu mandar fazer um cocar, uma pena única de arara vermelha. Eu tinha que ter a pena vermelha mas, em alguns momentos, eu tinha que enfiar algumas penas azuis e depois voltar com as penas vermelhas para quando aquilo se misturasse, aquela marca tivesse um azul pulando no meio do vermelho. Isso eu fiz com o verde quando eu botei o azul, eu fiz no amarelo quando eu botei o laranja. E isso é uma coisa que você entende no fazer, e na vontade de pintar o todo em movimento.

GV Você tem uma visualização de um quadro vivo, em que tem um espectador. Aonde está esse espectador ideal que você está pensando. Porque o quadro tem um espectador aqui, do lado de fora. Mas no caso do que você está falando, você tem um espectador que está aqui, outro está ali, e tem a televisão. Então esse é um fenômeno desafiante porque você está produzindo uma pintura andante, uma ópera andante, com toda essa edição de cores. Você entra com cores quentes, depois entra uma cor fria, então você está pintando também no tempo, no tempo-espaço. Eu fiquei encantado por você falar dessa forma, por que você está pensando numa pintura que tem um sequencial. Se vai começar com azul, se vai começar com vermelho, se vai começar palha e dourado. Então você pensa o roteiro das experiências sensoriais da cor. Aí eu volto para uma pergunta que nos traz aqui. Quando você desloca sua produção artística para uma exposição. Como é que está essa borda quando você vai para dentro de uma galeria expor?

LV Então, aí quando surgiu a possibilidade de levar parte do meu trabalho para o Paço Imperial, isso em 2017, o interesse em conduzir a exposição foi pelo conteúdo do enredo. Por ser um enredo sobre a religiosidade ele despertou o interesso do patrimônio artístico, porque se debruçava na arte sacra, em todo esse universo religioso. E o meu trabalho é muito pautado nessas referências. E quando eu levei isso para 
dentro do Paço, aí eu tive uma preocupação contrária. Eu não quis levar para o paço o carnaval enquanto essa atividade festiva. Eu quis fazer uma coisa que mostrasse os bastidores do processo artístico. Porque o carnaval já vive há muito tempo esse esvaziamento da produção artística. Das pessoas não olharem essa produção como uma produção de arte gigante, como arte plena. Tem o preconceito da sociedade brasileira como um todo com relação ao carnaval. Mas tem o preconceito do desconhecimento dos saberes do carnaval, da produção artística, do figurinista, do artesão, de que existe um figurino, que existe um processo de criação como esse que nós estamos debatendo, que existe a produção da pesquisa. Então, para o Paço, eu quis levar as coisas no micro. Tanto que quando eu fui expor figurinos eu quis fazer miniaturas. Ao invés de levar aquele macro do carnaval, uma alegoria, fazer uma maquete pequenininha. Eu queria chamar a atenção para as particularidades, para os figurinos, para o desenho, para o fazer, para essa questão do bastidor da criação, que as pessoas na maioria das vezes desconhecem mesmo.

GV Seria quase que o processo de concepção?

LV Sim

CS $E$ você fez inclusive uma parede com o cronograma de 9 meses de construção do carnaval. E nesse cronograma você contava cada etapa, cada passo, e como era essa vivência lá dentro. Quais eram os atores responsáveis por cada etapa? E quando você entrou lá no Paço, que é uma instituição conhecida na cidade, como se deu essa relação com esse novo espaço de exibição?

LV Eu me senti artista duas vezes. Na verdade, eu sempre me senti artista. Mas quando eu digo "me senti artista", quero dizer me senti reconhecido como artista. São duas experiências totalmente distintas. Eu me senti o artista carnavalesco, e isso é muito curioso porque eu fiquei na Caprichosos de Pilares um ano trabalhando, vivendo aquilo ali, mas eu não me sentia um carnavalesco. Eu tinha um preconceito com essa figura do carnavalesco, de como as pessoas conhecem a figura do carnavalesco, essa pessoa enfeitada, essa pessoa emplumada. Não é só com a figura, mas com o que virou a produção artística do carnaval. E de alguma forma, antes de conhecer o que era carnaval eu sabia quem era o 
Fernando Pamplona. Eu não via as coisas que o Pamplona fez. Nem no Youtube tem. Mas sim, a referência da postura do carnavalesco que eu admirava, e que se eu quisesse ser alguma coisa próxima, era o Fernando Pamplona. A coisa da consciência do que estava fazendo, da ruptura de tirar uma comunidade negra que gostava de se vestir de Rei e Rainha com peruca e sapatinho de laço, para vestir de uma corte negra, de exaltar valores negros, de apresentar para essa comunidade Zumbi dos Palmares, e outras personalidades negras. Então tinha muito isso. $\mathrm{E}$ aí o Pamplona era um cara que eu acompanhava. Acompanhava o posicionamento político, acompanhava a postura, acompanhava a maneira como pensava e acompanhava um pouco das histórias do que ele contava. E ele contava a maneira como ele viveu a escola de samba de uma forma muito saborosa, muito divertida. Eu tenho ele como uma referência da postura do artista para o carnaval. Não esteticamente, porque eu não vi. Mas da consciência do papel do artista. Aí eu fui para a Mangueira e fiquei ali um tempo. Quando eu cheguei, sofri muito preconceito, pela pouca idade, pela falta de saberem quem eu era. Era meio "o que que esse garoto vai fazer, vamos cair, já estamos em décimo, vamos para pior". Eu sofri muito preconceito com relação a isso. Eu não tinha nome, era chamado de garoto, "fala com o garoto". As pessoas chegavam aqui, batiam na minha porta, me viam sentado desenhando e falavam assim "posso falar com o carnavalesco?". Então não me reconheciam como o cara sentado na mesa desenhando, aquele não era o carnavalesco. "Você pode chamar o carnavalesco?" Aí eu falei "não, o carnavalesco sou eu", "Ah tá, é você. Novinho, né?". Então eu tive muito esse tipo de problema. Mas eu sempre gostei do samba, do ambiente do samba, de roda de samba. Eu gosto muito de ir à quadra, daquele ambiente de viaduto, de gueto, de beco, de cerveja. Um dia, eu já era carnavalesco, eu saí da quadra e fiquei no viaduto, embaixo do morro da Mangueira. No ambiente que eu gostava, uma coisa da cerveja, do contato com a comunidade, da música, de tudo isso. E aí eu bebi muito, fiquei bêbado, e dancei, e fumei, e cheguei em casa tarde, e minha esposa brigou comigo. Quando eu me deitei na cama eu estava me sentindo o Fernando Pamplona (risos). Naquele dia eu me senti o carnavalesco artista. Não pela produção de arte, mas pelo viver da experiência daquele ambiente. Naquele dia eu entendi muito o que era o papel do carnavalesco para uma comunidade. E naquele dia eu também desmistifiquei algumas referências artísticas que eu tinha. Porque eu sou fã da estética da Rosa. Eu acho a Rosa uma das artistas mais geniais. Mas de alguma forma eu acho que o que a Rosa propõe é muito eurocêntrico. De alguma forma, hoje isso me causa uma estranheza que antes não me causava. Então isso me dá um certo desconforto, alguma coisa assim. 
Então nesse dia eu me senti artista. Eu me entendi como artista. Eu entendi a importância da cerveja, do cigarro, do suor e da música para o meu trabalho. Daquele ambiente de viaduto, de viela, de infiltração. E a outra vez foi quando esse mesmo artista pegou os figurinos dele, pegou essa coisa dele e aquilo estava no Paço Imperial. Um negócio assim, que era o que eu queria fazer quando eu tinha dezoito anos na universidade e que eu achava que o carnaval não era lugar para isso. E o que me levou ao Paço foi justamente o trabalho que eu fiz para o carnaval de 2017. Também me senti artista.

CS Mas, ao invés de mostrar uma obra bonita, acabada, você poderia ter feito uma exposição impactante, impressionante. Você poderia ter levado um carro alegórico... Mas você optou por uma desconstrução. Voltando ao início da conversa, quando você falou do seu processo de desconstrução e também de uma postura muito didática, de explicar para o grande público. Porque, embora o Paço seja um lugar quase apenas de exposições, é um lugar muito visitado por todo tipo de gente. Tem um público grande, muito eclético, muito misturado, e ali você queria explicar. Aquela exposição mostrou o seu processo de trabalho, o processo de trabalho dentro do barracão.

LVÉ, sim, falar para todo mundo.

GV O que me chama a atenção, estou te conhecendo hoje, é a sua lucidez de pensar contrafluxos. E isso é o artístico. E é de uma coragem extrema. Você poderia querer trazer a sua conquista de um lado para um outro campo, e que provavelmente, talvez reforçasse até o clichê da divisão dos campos. E ao mesmo tempo você falou muito desse não espetáculo, sabendo que o contorno tem uma expectativa de espetáculo. Então você lida com um contra fluxo muito difícil. Porque vem gente do mundo inteiro, e é a Mangueira, muita cobrança do contorno, é uma expectativa. $E$ você conseguir fazer esse esquivo.

LV Com essa informação dá para você imaginar o meu orgulho de ter ganho o carnaval de 2019 em cima de escolas luxuosíssimas. Ganhar da Viradouro, de um projeto milionário, ganhar da Vila Isabel com um projeto milionário. Ganhar levando monumento pichado, ganhar com produção de bandeiras. Aquela bandeira ela assumiu aquilo que talvez 
uma outra escola levasse numa alegoria. Eu quis levar uma bandeira. Aquilo é um pedaço de pano.

GV Eu não posso sair hoje sem dizer o seguinte: Você mexeu com a alma coletiva de um estado que está desencantado. Então houve uma vitória não só sua, uma vitória de todos nós, eu estou emocionado, porque você tocou, porque a gente está vivendo um momento de desencanto, principalmente na cidade do Rio de Janeiro. Então essa sua vitória, de você ter sido um canal, e de coragem. Porque realmente no momento que todo mundo entra na avenida, abraça um processo inusitado. Então aquela bandeira ali não é um pedaço de pano, é o simbólico que você conseguiu atingir. E eu gosto muito de tratar de uma dimensão crítica e estética da arte, dessa unidade rara entre jogo, festa e simbólico. Porque se você só tem jogo, a estética fica limitada ao jogo da criação, e perdendo a comunidade. A festa é uma festa onde todos se pertencem, então a conquista é da e com a comunidade. E a terceira dimensão é o simbólico, o simbólico é isso que levanta uma alma carente coletiva. Todos se sentem participantes de uma possibilidade de futuro, num mundo totalmente desencantado. Você certamente fez algo que é o que todo campo da arte deseja.

LV É muito louco isso por que eu acho o desfile de 2019, o meu melhor carnaval. Eu sei que no campo estético ele está longe de ser o meu melhor carnaval, porém no campo da Arte que eu quero, do que eu quero produzir enquanto arte, tentando me livrar das amarras da beleza, do luxo, dos volumes, do brilho, esse é o melhor, esse é o melhor de todos. Porque esse é, por exemplo, o monumento pichado, é um Duchamp, se eu tivesse que colocar, usando a arte, como criar esses paralelos. Um livro aberto com corpos ensanguentados é um negócio que para o carnaval não tem a beleza, mas é o que eu quero fazer.

IA Você traz a dimensão do conceito para o carnaval.

LV E ganhar com isso, para mim é muito louco. Ganhar dos três carros acoplados da Vila Isabel.

GV A pressão pelo espetáculo é gigante. 
IA E tem uma dimensão da globalização também, do outro enfrentamento com que você tem que lidar. Porque isso tudo é muito rapidamente apropriado e transformado numa imagem, e você joga com uma outra, muda essa visibilidade.

LV Mas eu acho que eu também colaboro para essa coisa. Eu tenho a consciência que eu faço isso. De que eu jogo muito aquilo que eu produzo para o todo. Uma das coisas que me alegrou foi saber que essa bandeira virou uma bandeira de todo mundo. Não é mais minha.

IA Mas é uma bandeira porque ressignifica uma bandeira.

LV Sim, mas quando você fala da globalização, é uma imagem que ficou. Essa bandeira ficou para as pessoas. E eu quero fazer coisas assim.

CS Foi uma das imagens mais reproduzidas durante o carnaval, e depois, no Facebook.

LV Você vai na manifestação política hoje em dia tem alguém com essa bandeira. E eu não mandei fazer, ninguém mandou fazer. Você vai no Mercado Livre, bandeira Mangueira, já tem para vender no Mercado Livre, alguém fez. Então eu penso muito nisso, de você fazer umas coisas e jogar, sabe...

GV Mas atingiu o simbólico. E isso não se planeja, você conquistou, é uma intuição. Agora, me lembrou, voltando ao Israel Pedrosa, que todo mundo aqui já deve ter estudado. Um dos exercícios do Israel Pedrosa, não sei se vocês se lembram, tem uma bandeira do Brasil, e você tem que fazer aquele exercício de contar até 60 fixando o olhar, e aí a cor complementar surge. Veja isso, não sei se você estudou essa fixação da luz de uma cor e aí depois você fecha os olhos e surgem as cores complementares. E nesse exercício é fascinante porque você olha uma determinada bandeira do Brasil, nas cores complementares, para fechar os olhos e surgir o verde $e$ amarelo. Mas, só por curiosidade, porque o que você atinge não é algo da técnica. É algo de tocar esse inconsciente por terapêutica. Porque há uma terapêutica social de uma potência de restaurar o ânimo de uma cidade ou talvez do país. 
CS Há muitos artistas que curtiram o carnaval, e inclusive trabalharam para o carnaval. A Lygia Pape, o Carlos Vergara, e mais para trás Lasar Segall, Santa Rosa, Wlademir Dias Pino.. Agora, o que você faz é outra coisa. Você está ali dentro. A Lygia fez decoração para a avenida Rio Branco, o Vergara tem uma série linda de fotografias sobre carnaval, mas você não faz nada sobre carnaval. Até mesmo o Hélio Oiticica, quando sobe o morro da Mangueira, numa intenção de se apropriar daquele morro, daquela vida, daquela vivência, e trazer isso para a obra de arte. Ele aí faz os ninhos e traz a experiência da Mangueira. Mas sua atitude é totalmente diferente. $O$ que o Leandro faz como artista é trabalhar de dentro, é modificar a escola por dentro. É criar o carnaval junto com a comunidade como você diz. Mas é uma coisa nova, totalmente nova.

FF É interessante, que isso tudo que você falou e tudo que a gente está falando aqui, a gente pensar como o processo é a tua criação. A tua criação é aqui o barracão. A Escola é uma consequência. Quando você foi para a galeria você abriu mão dessa criação. A criação é algo que vai acontecer posteriormente. Mas o que te interessou foi chamar a atenção para o processo. O seu trabalho está nesse momento, que é o momento da simbolização, que é o momento que você vai criar, simbolizar aquilo que você tem. Então acho que é interessante pensar por esse lado, essa valorização desse momento, que é diferente do que normalmente os carnavalescos vão fazer, que é valorizar, a estética que vai surgir no final. O processo é menos importante. Então eu acho que essa forma de você pensar, ela reflete nesse seu trabalho. E eu imagino que ela vai refletir no ano que vem mais ainda, pelo que eu estou imaginando, pelo que eu já vi, por exemplo, do logotipo da Mangueira, que tem toda uma agressividade ali. É um Cristo Redentor verde e rosa, mas ele é preto e branco.

LV Na verdade no enredo da Mangueira para o ano que vem, eu continuo nessa questão contra-hegemônica. Eu apresento um cristo periférico. Eu imagino o retorno da figura de Jesus Cristo no Brasil de hoje. O que aconteceria com essa figura. Eu falo que é o Jesus da gente, ele é periférico, contra-hegemônico. É um momento em que a gente vive em um país em desalento e a figura de Jesus Cristo, ele foi levado para a trincheira da ultradireita, e o que eu tento fazer com o meu carnaval é um sequestro de Jesus da trincheira da ultradireita para um Jesus do mundo, um Jesus periférico, chegado a liberdades. 
GV É empolgante você usar a palavra de retorno. Porque na verdade o Jesus histórico ele era periférico, ele era marginal, ele era da rua, ele que conversa com as mulheres. Essa história foi deturpada e virou Roma. E você quando põe verde e rosa. Me encanta pensar verde e rosa porque verde e rosa são cores de cura. E me vem à cabeça, qual a diferença entre o que você está fazendo e o Joãozinho Trinta. É a cor. E o que significa a cor na arte. Até porque a arte enredada no intelectualismo, se afastou da cor. Porque a cor passou a ser interpretada como superfície e maquiagem. Então os coloristas são raros, porque cor mexe com a alma. Cor é sedução e tudo. Então, quando a história da arte se afasta da cor, e se dirige mais para o conceitual, não é a toa. Porque a cor vira maquiagem, cor fica fácil. E o mundo está tão descontente. Então você mexer com questões profundas, mas manter a cor, essa dimensão, o Joãozinho Trinta não fez dessa forma. Posso estar enganado. Essa combinação entre densidade crítica e mantendo a cor é o que está me interessando no que você está apresentando.

AS Eu fiquei ouvindo também tudo isso que vocês estão falando. Essa coisa linda que o Vergara fala do simbólico. Esse furo numa certa espetacularização que a Inês aponta... essa bandeira que já é história. Você falou uma coisa que eu achei engraçada. Um certo preconceito da grande população com o trabalho no carnaval. É claro que tem uma escritura no seu trabalho, que é a rua junto a questão política ou a política na encruzilhada da rua. Fiquei pensando como seria essa negociação, como é que isso se deu também na prática. Por exemplo, em 2017 a Mangueira apoia o Crivella, e um ano depois o mesmo Crivella vem como um Judas. Então como é que isso se dá? Como você sente esse carnaval e o efeito disso também numa escala maior. Porque a gente entende que isso é um trabalho de um artista e dessa comunidade toda. E por outro lado eu também fico pensando nas três instâncias políticas que nós temos hoje, que a despeito de qualquer coisa e qualquer opinião que a gente tenha, essas pessoas foram eleitas. Então como é que isso se dá um pouco na ordem do seu desejo e também nas mediações com a comunidade. Nos efeitos políticos e nas estruturas dentro e fora do barracão...

LV 2018 eu acho que ele pode ser olhado como um marco, não no sentido macro, mas um marco que determina uma questão específica ali em 2018. E eu digo um marco porque 2018, 2019 e 2020 conversam. Então se eu vou com um carnaval em 2020, eu somo cinco carnavais na Mangueira. Se três dialogam, se minha trajetória na Mangueira acabar após o carnaval de 2020, esses três carnavais traduzem um marco, um 
direcionamento para o que eu estou fazendo. Então eu tenho essa questão muito forte de deixar no trabalho que eu produzo uma marca minha, uma marca da minha maneira de pensar. Eu gosto de olhar para os meus trabalhos da maneira como ele é registrado, que é vídeo e foto. Eu gosto de olhar para os meus trabalhos e reconhecer um determinado período da minha vida, uma determinada situação, uma determinada maneira de pensar. Então em 2018 eu percebia que o meu radar apontava para essa questão desse avanço conservador, desse pensamento conservador. $E$ isso coincide com a chegada do Bispo na gestão municipal da capital cultural do país. $E$ isso é muito louco porque o Crivella anunciou o corte e a subvenção enquanto ele fez uma associação na justificativa, ele sempre associou o carnaval com uma festa. Ele nunca olhou para o carnaval como uma atividade artística e cultural. Então eu lembro bem a fala dele "O que vocês acham mais justo? Investir o dinheiro para alimentar as crianças da creche ou gastar o dinheiro em três dias de festa?". Claro que a questão não é o dinheiro, até porque o que eu propus, depois do que ele disse da importância do dinheiro para alimentar crianças ou carnaval, eu batizo o trabalho que eu apresento naquele ano como "Com dinheiro ou sem dinheiro eu brinco". Então não era a questão do dinheiro que me importava, mas era a importância de mostrar algo que defendesse o carnaval enquanto uma atividade histórica, artística e cultural, viva, lúdica. E aí eu organizei esteticamente o meu desfile com uma estética e uma seleção de repertório que o conservador nega. Era um desfile que tinha como segunda alegoria um botequim. Era um desfile que tinha como espaço de ocupação a rua, que era o Cacique de Ramos que desfila na rua, o Bola Preta que desfila na rua, a Banda de Ipanema que desfila na rua. Era um desfile em que eu levei foliões da rua, com as fantasias da rua para desfilar numa alegoria que tinha como uma das esculturas principais a Laura de Vison, a estética LGBT. Que tinha uma escultura da Isabelita dos Patins. E no meio da festa, uma tábua com Crivella como um Judas, como um boneco de Judas no meio da brincadeira. Então aquilo ali era uma resposta, era um ataque ao conservadorismo. Era um ataque a essas pessoas que pensam que o sentido da festa é menor.

GV É exatamente isso que eu ia falar. Porque a gente tem festa, e aí você falou comunidade, a gente só forma laços, quando você fala do viaduto, você sente encarnado ali. Então não é uma festa falsa, mas é uma festa de abraçamento e de alegria. 
LV O Simas usa uma frase maravilhosa. Ele fala que a festa espanta a miséria. Não só a miséria física, mas a miséria intelectual também. E aí isso é 2018. Em 2019 esse conservadorismo cresce e a gente experimenta a chegada do conservadorismo no âmbito nacional. A gente está falando agora da presidência da República. A gente está falando agora de um conservadorismo que nega as questões indígenas, que nega a questão popular, que reforça questões racistas, que reforça questões ligadas à ideologia de gênero. E aí eu venho e faço um carnaval, batizo como "História para ninar gente grande". No momento em que é defendido a implementação do Escola Sem Partido e começa todo esse debate do papel da educação, de até onde a educação pode ir na formação intelectual de uma pessoa. Quando começa esse debate eu quero fazer esse carnaval de contra-hegemonia, de exaltar figuras marginalizadas e rir, e transformar em caricatura heróis nacionais, vultos históricos nacionais. Aí vem 2020. Isso continua. A gente vive agora um momento do reforço desse conservadorismo, com o avanço de bancadas evangélicas, com a questão da censura, da utilização dessa mistura explosiva de religião, de Deus acima de tudo.

AS Você teve um tripé que a Arquidiocese pediu para...

LV Isso foi antes, isso foi em 2017.

AS Mas você já viveu isso de alguma maneira, ou não?

LV Eu não encaro muito isso como uma censura, não sei se foi. Em 2017 especificamente eu queria fazer um Cristo sincretizado com Oxalá. Eu tinha um enredo sobre a devoção popular. Um dado importante da devoção popular é o sincretismo religioso. Era uma questão importante. Eu no ano anterior, isso também é uma outra coisa que a gente não tocou, mas eu vou tocar de uma forma um pouco mais superficial, mas acho bacana vocês tomarem conhecimento disso porque eu falo inclusive muito pouco sobre isso, pois além dessas questões, eu costumo impregnar meu trabalho muito do Leandro humano, do homem que em 2019, no meio do carnaval, se divorcia. Quando eu falo do divórcio é o divórcio da esposa mesmo. Que se divorcia e que quer colocar também em seu carnaval isso enquanto um dado. Mas um dado subjetivo que só interessa a mim, que só é identificado por mim, e talvez por pessoas muito próximas. O carro do Dragão do Mar, inicialmente ele não seria 
branco e preto, mas dourado. Era um navio negreiro com um dragão. Um carro em exaltação ao Dragão do Mar, uma figura importante no processo da abolição brasileira. Então ele foi pensado inicialmente para ser dourado. Dourado como uma cor majestosa. Um navio negreiro majestoso. Uma joia dourada. A ala que vem a frente ao carro é uma ala de estandartes, é a ala do Luiz Gama, com estandartes amarelos. O amarelo e o dourado criariam uma massa de cor expandida, de tom sobre tom unificado. Mas no meio do carnaval eu me separei. Um processo sempre desgastante de combate, de embate, e eu queria de alguma forma registrar esse combate, esse drama, essa questão. E minha ex-esposa é negra e eu sou branco. Então eu resolvi que o contraste do branco e do preto ia entrar no choque de cor do carro. Ele é dourado porque ia ser dourado, mas o branco e o preto entram como um dado que registra um momento específico da minha vida. Estou falando isso porque quando você fala do tripé de Oxalá, Oxalá entra no carnaval de 2017 porque no carnaval anterior, de 2016, em função do meu contato com a Bethânia e da proximidade do enredo de 2016 com o universo do Candomblé, eu acabei descobrindo que eu era filho de Oxalá. E eu fui campeão do carnaval de 2016.

IA É engraçado você falar desse dado biográfico, que entra na sua narrativa, o que também é uma diferença dos seus carnavais. Eles trazem muito da biografia das pessoas, trazem nomes próprios. Isso faz toda diferença, não é só um personagem mítico, talvez eu esteja voltando a alguma coisa que eu tentei falar no começo. Fico me perguntando como é que é essa sua construção, que também tem uma pesquisa histórica de vários livros. Imagino que você pesquise muito para conseguir articular tudo isso. Mas traz essas identidades das pessoas, essas biografias. Eu acho que isso traz uma imanência da vida. É sobre uma vida antes de qualquer outra coisa.

LV Tem tudo isso. Os meus carnavais eles têm uma memória afetiva muito grande. Os saquinhos de Cosme e Damião são saquinhos que eu corria atrás quando eu era criança no subúrbio. Bate-bola é que não falta, eu sou apaixonado por bate-bola. Tem uma memória afetiva, que é impregnada dessas questões, de colocar, de tirar e de estar sempre envolvido com isso. E 2020 é isso. Voltando ao que a gente estava falando, em 2020 continua nessa questão. E esse Jesus de 2020 também é um Jesus meu, também é um agradecimento porque eu tive um ano de 2019 difícil e aí a gente começa a botar contornos e criar coisas. É uma retribuição a algo que eu acho que Jesus fez comigo em 2019. Papo meio 
Baby do Brasil (risos) mas tem um pouco isso. $E$ isso tudo vai sendo misturado. Falei no começo de uma bacia, então, está tudo nessa bacia.

IA $E$ a conversa com a música, entre os compositores e a sua criação plástica? Porque tem o movimento sobre o qual estávamos falando. $O$ Guilherme Vergara chamou atenção para esse quadro vivo que você faz, mas nele tem a música, tem os ritmos. Isso também é cor. Como isso vai sendo processado, ao mesmo tempo? Como é que vai evoluindo?

LV Vai sendo construído. Na verdade, no trabalho do carnavalesco a gente tem essa produção artística. Tudo isso que eu falei aqui para vocês, de alguma forma eu tento transmitir para os compositores do samba. Isso é apresentado através de uma sinopse, que é um resumo traduzido musicalmente por um outro artista e depois retraduzido por mim. Também, é uma coisa cantada por um outro, com uma outra verdade, com um outro simbolismo. Então são muitas verdades, é a verdade de muita gente, são muitas camadas. Eu acho que é isso que torna a produção artística para o carnaval tão fascinante. E é por isso também, talvez, que eu acho que as pessoas têm a dificuldade de entender o carnaval como essa arte grande. Porque as pessoas têm muito a ideia da arte grande realizada de forma isolada. E a arte do carnaval ela é múltipla. É muita gente para fazer, é muita mão, é muita gente para cantar, para viver, para personificar, para acontecer. É um negócio que não é meu. Quando eu olho eu me identifico, mas tem muito mais pessoas. Existe por exemplo, o morador do morro da Mangueira. Eu faço isso aqui tudo, isso aqui tudo é meu, mas o morador do morro da Mangueira, para quem isso aqui talvez seja o único motivo da alegria no ano, isso pertence muito mais a ele do que a mim. Então é meu, eu olho isso aqui. Aqui tem a minha história, aqui tem o meu divórcio, aqui tem minhas escolhas, aqui tem as minhas tintas, tem os meus pinceis, mas é dele.

GV O que você coloca, sem se poupar de entregar algumas coisas da sua vida, é ao mesmo tempo o que celebra a conquista do seu trabalho, porque ela se torna um lugar de uma amálgama, onde as pessoas se reconheceme cantam e dançam. Então isso para mim é a arte do século 21. Aí tem uma dimensão das raízes da arte. Seja da África, seja do Oriente, essas raízes, os fundamentos da arte, foram perdidos quando ela ficou numa formação de artista que produz um objeto que vai ficar num circuito, numa bolha, para poucos falarem, em que não existe essa coletividade pertencendo a 
ela. Constantemente a gente vai lembrar o Hélio Oiticica indo para a Mangueira. Mas ele vai para lá a partir de um grande descontentamento com o circuito e com a vida individualista. Mas ele não vai transformar a Mangueira. Pode ter alguns amigos ali, vai tentar levar a Mangueira para - MAM, mas a Mangueira está lá. Agora o seu caminho, quando você fala de seu interesse é, espero que você continue nesse processo, para implodir as próprias conceituações que estão lá travadas de uma arte de bases europeias. Então o que você está falando, esse sentido do que você faz, ele é abraçado e só existe com o reconhecimento e o pertencimento de uma comunidade. Você está tocando em dimensões por vir. Não sei como é que você está vivendo esse porvir, desculpa, espero não estar falando demais, mas é uma responsabilidade e é uma incorporação de um processo crítico. Pra quem está lá, do outro lado, do campo da arte, a gente está vendo asfixias. Qual o produto? E aí eu te pergunto, para você, o que significa expor? Como é que você sente a diferença de ter levado essa exposição? $O$ que você teve de entrega e de retorno? Isso é interessante, como é que você vivenciou? A Cláudia já comentou, essa desconstrução, mas e a vivência? Que significados trouxeram, como você vê, e a diferença desse mundo?

LV A diferença é absurda! O contato, a possibilidade do contato. Aí, por isso que ela me perguntou, "você se considera carnavalesco ou artista?", eu estou tentando encontrar isso. E eu até cheguei a arriscar que eu tenho achado que o carnavalesco é um artista. Mas às vezes também eu fico na dúvida se todo artista não é um carnavalesco, no sentido contrário do caminho de lá.

GV Acho mais difícil.

LV Porque talvez, quando você fala assim "é mais difícil", eu não sei, eu estou tentando encontrar isso. Porque eu tenho certeza absoluta que o que eu produzo é arte. Isso eu tenho. 


\section{Transcrição Louis Barbaras}

Revisão técnica Inês de Araujo e Felipe Ferreira

\section{$1: 32: 21$}

